\title{
AN OUTBREAK OF VIOLENCE IN EASTERN ADONARA, INDONESIA, IN 1934
}

\author{
R. H. BARNES
}

Beginning in 1904, the government of the Residency of Timor and Dependencies (now Nusa Tenggara Timur) took steps to put into effect the new policies of GovernorGeneral van Heutsz to end the previous 'hands off policy' and subordinate local sovereignties to the Dutch East Indies Government by means of the 'Korte Verklaringen' [Short declarations] designed by the Islamic scholar and government advisor, Christiaan Snouck Hurgronje (Reid 1969: 271-72, 277-83). The first victim of the new policy was the Raja of Larantuka, who was deposed in that year because of his supposed involvement in the so-called Hongi Hinga, a war focused on Hinga, Adonara. As a result of Dutch military intervention in that dispute, the hand of the Raja of Adonara was greatly strengthened. In 1910 Captain J. D. H. Beckering collected firearms in what is now the East Flores Regency and registered the population (Beckering 1911). A stated aim of the Dutch authorities was to impose peace and order and in particular to suppress conflict between two ancient factions within the Lamaholot-speaking peoples of the region, namely that between the Demon and the Paji (Barnes 2005). Although they brought the Hinga incident to a conclusion to their satisfaction, the peace and order they sought never took hold. An example of this failure is provided by a bloody incident in 1934 in eastern Adonara.

\section{Background}

The Portuguese arrived in the Flores region early in the 16th century and the Dutch about a century later. The Portuguese and the Dutch were rivals in the trade of sandalwood from Timor and spices from the Moluccas. The Portuguese managed to make converts to Catholicism, but the Protestant Dutch had no such luck. The Portuguese encountered a division in the local population between Demon and Paji, which is reminiscent of similar divisions in the Moluccas, such as the Patasiwa and Patalima of Seran (Tauern 1918; Duyvendak 1926). The Portuguese became allied to an, eventually Catholic, Raja of Larantuka, Flores. The Raja of Larantuka and all those subordinate to him were Demon. The Dutch by contrast struck alliances with the so-called 'five shores', an extremely loose collection of small-scale Muslim principalities, including the Raja of Adonara, the Raja of Terong, and the Raja of Lamahala, all on Adonara, and the Raja of Lohayong and the Raja of Lamakera on Solor. The Muslim rajas were all Paji (Barnes 1987). ${ }^{1}$ This pattern remained until the government of Portuguese Timor became indebted to the Dutch East Indies and ceded control of 'its territories' in the Flores region to the Timor Residency in 1851. After negotiations between the governments of Holland and Portugal,

\footnotetext{
${ }^{1}$ The reader may find some parallel themes for the Moluccas in Andaya (1993).
} 
in exchange of money, Portugal transferred its claims to ownership of these territories to the Dutch in 1859. From 1851, the Dutch intervened increasingly in the affairs of both the domain of the Raja of Adonara and that of the Raja of Larantuka.

The Demon and Paji populations are dispersed in an irregular pattern through East Flores, Adonara, Solor and Lembata. The division is encoded in myth and was linked to ritual warfare and head hunting. As shown by Arndt (1938), there were never wars in which a unified group of Demon opposed a unified group of Paji. On the contrary, the Demon and Paji conflicts were always small-scale affairs and they were always provoked by a specific incident or ritual need. Much the same sort of blood-letting occurred within both groups as well. Furthermore, alliances across the divide occurred from time to time. For example sometime, probably in the mid-19th century, the Raja of Adonara helped the Demon region of Kiwangona, then engaged in a war with a village called Libu, by persuading troops brought by Libu from Timor to switch sides and support Kiwangona. For some time afterwards, the Raja of Adonara and Kiwangona maintained a kind of alliance. In addition marriages could be contracted and friendships struck up between individual Demon and Paji.

Later in the 19th and early 20th centuries, the Paji village of Hinga rebelled against the Raja of Adonara. Paji Hinga received some support from Demon Kiwangona. At this juncture the Dutch stepped in, to the cost of the Raja of Larantuka and the head of Kiwangona. Not infrequently, warfare was linked to revenge for a previous death. On Adonara there are specific rituals conducted in preparation for such retaliations ([Lewokeda] 2002).

\section{Demon and Paji}

The division between Demon and Paji was first mentioned by Cacegas and de Sousa in 1678 and subsequently by Santa Catharina in a publication of 1733 which reports events from 1630 to 1706 (Cacegas and de Sousa 1678: 357; Santa Catharina 1733: 792; Rouffaer 1923-24: 222). Cacegas and de Sousa were writing about events at the end of the 16th century. Both of the early Portuguese publications refer to the Demonara and the Paginara (Pajinara). These expressions are still current among Lamaholotspeaking people. Nara means 'group', but in some contexts of use can mean 'troops'. Rouffaer wanted to derive nara from old Javanese and to relate the names Demon and Paji to the old Javanese titles Děmung and Panji. Be that as it may, the division is unlikely to be a borrowing from the west, although it could be seen to fit the views of some early Dutch scholars such as Rassers which held ancient Javanese society to be characterised by a similar dual division (Rassers 1959; Fox 1986). De Roever (2002: 76-80, 194-95) gives a useful summary of the published literature on the division as well as presenting for the first time an extract from a report by the oppercoopman or principal merchant of the Solor fort, Jan de Hornay, which mentions the division. De Roever tells us that de Hornay mentioned the Demon and Paji in his correspondence with his Dutch East India Company superiors in Batavia between 1625 and 1630 and he also reproduces the text of a treaty de Hornay contracted with the Portuguese merchant Francisco Fernandes. This treaty dismayed the directors of the Dutch East India Company who ordered de Hornay's arrest. De Hornay deserted to the Portuguese and with a local woman founded a militarily and politically important lineage on Flores and Timor (Barnes 1987: 229-30).

The ethnographically richest account of the Demon and Paji hostilities was provided by the Catholic priest and anthropologist Paul Arndt, who was commissioned by the local government to make ethnographic enquiries into the matter, especially on Adonara which by then had acquired the reputation of being the 'island of murderers' 
(Arndt 1938; Vatter 1932: 157-85). It is impossible to determine the exact age of the conflict between the groups. Since the earliest Portuguese relations showing any knowledge of the people in the interior mention the Paji and Demon, we might well suppose that hostilities had begun long before the Europeans came to the islands. An extensive myth which Arndt recorded in Larantuka tells of the origin of the enmity in a struggle between the two brothers Igo and Enga for sovereignty over Larantuka. Igo and Enga appear in the genealogy of the Raja of Larantuka at a time which has been estimated at either the end or during the first half of the 16th century (Arndt 1938: 42; Wertenbroek n.d.). Estimates obtained by allotting a given average duration to each generation mentioned in a genealogy are rarely accurate for a number of reasons; but the attempts just mentioned would place the beginning of the rivalry at a hundred to two hundred years before the publication of the first notices of the antagonism and about the time of or a little after the arrival of the Dominican priests in the mid-16th century, sufficient time for it to have spread to a large portion of the inhabitants.

However, other myths suggest that the rivalry existed before Igo and Enga came to strife (Seegeler 1931: 79-80), and the brothers appear in so many other myths and at various stages in so many other traditional genealogies that the historical reliability of any of them is doubtful. It is very likely that the rivalry is an instance of a common and quite ancient feature of Indonesian social organisation. These considerations suggest that the conflict had begun prior to the historical period.

With few exceptions the available ethnographic information comes from the Demon. Arndt obtained almost nothing from the Paji on Adonara (Arndt 1951: vii-viii). I have acquired little additional information about the division in two periods of intensive research living among people deemed to be Paji. In Arndt's experience, the Paji are very reticent about discussing the matter and are even despondent or depressed when it is mentioned. The Demon, on the other hand, are quite self-assertive and in general are willing to give information about their relations to the Paji and take pleasure in deriding them (Arndt 1938: 3). Whether their attitudes remain the same today is not something I could affirm. It is said by the Demon that the villages of both sides formerly lay scattered about together and were united in small alliances, especially in East Flores (Arndt 1938: 47). According to the Demon, the Paji were formerly much more numerous than the Demon. It is commonly reported that they were the original inhabitants, but individual clan histories show that such was not always the case. However, through continual warfare, the Demon gradually pushed the Paji back until they now occupy for the most part marginal and less desirable land in each of the islands.

The importance of conquest receded in the 20th century due in large part to the measures taken by the Dutch. Nevertheless, although the Dutch outlawed murder and warfare, they seemed incapable of completely controlling them. In the Paji district of southwestern Adonara, Arndt was told that fighting occurred most often during a drought (Arndt 1938: 48-49). The statement of his informants here accords with those from Demon regions (Arndt 1951: 235). In West Adonara he was told that drought was a sign that Lera Wulan (God in the guise of the sun and the moon) was hungry and thirsty and required human blood and skulls. A war would be fought in order that someone be killed and sacrificed to Lera Wulan. Arndt was told that the souls of men who die in war go up to Lera Wulan. For that reason the Demon and Paji may never make peace. One informant observed,

The peace imposed by the Company [Dutch East Indies government] is no true peace, only a fake peace (sare opeñ - deceitful peace). Why 
does the Company forbid us to make war? The Company makes war itself and kills people in them. It made war around Ilé Mandiri [the prominent volcano behind Larantuka]. How can it then forbid war? (Arndt 1938: 8-9).

Vatter mentions that formerly in Leloba, Flores, a war would be fought after a harvest in order to return strength to the land (Vatter 1932: 106). Lera Wulan is said to have created the division in order to ensure that he would always be supplied with human heads (Arndt 1938: 25-26). When a village temple was built, a human head had to be placed at the base of the first main support, and as a rule this head is from an enemy village, usually from the Paji (Arndt 1938: 48; 1951: 81-82; see also Barnes 1993). In Kawa Liwu, Flores, Arndt was told that if in building a village temple a part did not fit, then a head would be taken from the Paji and blood would be spread on the intransigent part. After this treatment the part would certainly adjust (Arndt 1938: 22, 47-48; 1951: 81-82). Furthermore, should a Paji wander into a Demon area or should the reverse occur, the stranger would be immediately killed and offered as a sacrifice to Lera Wulan (Arndt 1938: 9).

However, this last requirement was not so strictly followed as the assertions of some of his informants would suggest. A number of villages from the two groups had by Arndt's time contracted special treaties which had the purpose of ending hostilities between them. The Paji of Wulubelolong, East Solor, and the Demon of Tanah Boleng, East Adonara, had an accord of this sort. In particular, when they met at the market in Waiwerang, Adonara, there was an exchange which confirmed and consolidated the agreement. The Paji received betel from the Demon, who in turn received palmwine from the Paji. When accompanied by someone from the other village, it was possible to travel in the territory of the enemy without being challenged as to one's identity and then killed. However, the accord had been broken some years before Arndt's visit. The Demon of Pamakayu, Solor, entered a similar alliance with the Paji from Terong, Adonara. Arndt gives several other similar examples and mentions that marriage also occurred across the divide (Arndt 1938: 49-50).

\section{The outbreak of 1934}

Vatter titled his chapter on Adonara, 'Adonara, island of murderers'.

There is no region in the east of the Netherlands Indies in which there is so much murder as on Adonara. Almost all murder and violence, raids and brutal offences which are brought to trial in Larantuka are committed by Adonarese. No other island in the east of the Indian archipelago has so bad a reputation both among Europeans and the inhabitants of neighbouring regions as this island, which is blessed by nature with beauty and fertility and whose population is distinguished from the neighbours by exceptional intelligence, enterprise, adaptability and limitless vitality. It is not just the curse of blood feud which burdens this land and in fatal linkages year in and year out demands victims over and over again. A special emotional and mental structure, foreign to the other people of the Solor-Alor archipelago, also plays a role: an exaggerated sensitivity to offences and insults, however harmless by nature, towards all friction and misunderstandings, as is unavoidable in communal life, a sometimes grotesque vanity and 
megalomania, combined with marked feelings of inferiority about their own race and culture, joy in war and blood-letting, paired with mistrust and fear. Finally, an unmistakable inclination to brutality and cruelty, or perhaps more correctly, an untameable drive to give spiritual tensions an explosive resolution through acts of violence. One could also describe Adonara as the island of immoderation. For European sensibilities, provocation and response among these people stand in no relationship. Inducement and reaction seem to us to be beyond any rational relationship (Vatter 1932: 157).

In 1929 Vatter visited Lamabunga, Adonara, for a few days, where the men described for him their lives. Prominent themes were war, murder and imprisonment. Even among the young many had already served prison terms, always for causing bodily injury or for taking part in wars. Almost every year there was fighting with the village of Hinga (thus a continuation of the events of 1904). On the evening of his last day in Lamabunga before his departure to Hinga there was much unrest because Lamabunga expected an attack from Hinga, which Lamabunga deemed to have been held off pending Vatter's departure. In Hinga he found that because of his presence, Hinga had decided to settle for a legal resolution (Vatter 1932: 172, 176).

Dietrich (1989: 78) comments that in the period 1906-1910, military engagement by the government in Flores and adjacent islands remained comparatively infrequent and was confined to the peripheries of the princedoms. Of the 25 rebellions on the islands from Flores to Lembata between 1910 and 1920 listed by Dietrich (1989: 96), 11 occurred in east Flores and on Solor, Adonara and Lembata, but only one of these (between Witihama and Tanah Boleng) involved the part of Adonara under the Raja of Adonara (Koloniaal Verslag van 1914: 30; Lulofs 1914: 470-71). However, as remarked by Arndt (1938: 50), the bond Hinga had established with Kiwangona during the Hinga war was never forgotten by them until the 1930s when a war broke out between the Paji and Demon villages of eastern Adonara. Arndt's account, taken from a letter of H. P. Peters, is as follows.

The Demon, perhaps intentionally in order to aggravate them, had hacked down banana trees in a field belonging to a Paji. The Paji then attacked and killed a Demon man in his field. The son of the victim who saw the killing ran to his village with the news. They retrieved the corpse and held a council in which they determined to take revenge. By coincidence on the same afternoon a man from Hinga arrived in the Demon region in order to negotiate about the marriage of his son. The negotiations lasted into the night. Around $8 \mathrm{pm}$ two men broke into the gathering and cut the visitor down before disappearing. In the same night the Demon set off to attack Paji who were in the government centre Waiwerang on the south coast to perform corvée labour on the roads. Fifteen Paji were sleeping on the cool cement floor of the market following their work. The Demon slipped in and killed four of them and severely wounded nine, of whom three later died of their wounds, although two escaped unharmed. On the next day the Paji lay in ambush on the border, where they surprised and killed six Demon, including two children between eight and ten years of age.

Thereafter both Demon and Paji stayed in their houses for fear. Soldiers patrolled through the region, but they helped little because the population knew them already. If a band set on murder took up positions, they placed guards to warn them of approaching soldiers, by for example calling wékak, wékak (cockatoo, cockatoo!), an agreed upon signal. Three days later Demon camouflaged with black and white colouration surprised 
and killed four Paji near Waiwerang, leaving their mutilated bodies behind. Two weeks later an agricultural consultant came into the Demon region and persuaded them that with his protection nothing would happen to them and talked them into going with him to their fields. However, the Paji of Watoone (a constituent of Witihama) lay in ambush on the border. When the consultant went on, the Demon remained on their fields. Suddenly the Paji attacked them and killed three men and two women and then mutilated their bodies. They cut a stomach open and stuck an arm upright in it. Heads were taken, and a woman's hand was cut off and carried on a spear to Witihama and Watoone as a war trophy, where it was hung on a tree. On the southern slope of the Boleng volcano, the Paji challenged the Demon four times to war. On the fifth, the Demon responded. Seven Paji and four Demon died. Thereafter the government put 20 to 30 men in prison and the killing and fighting ended for the time being (Arndt 1938: 50-51).

Another account of these events was written by the Catholic priest Stevanus Kopong Keda Lamahoda. According to this account, a person from the Demon village Lamalota was killed by people from the Paji village, Muda. In revenge, many people from the Paji village, Watoone, who were working as corvée labourers in Waiwerang were suddenly attacked one night around $11 \mathrm{pm}$, while sleeping in a store they were staying at, by people of Lamalouk, a village near Lamalota. The people of Watoone, who knew nothing of the attack, were thrown into panic. Eight people were killed, and many escaped with wounds. One named Sereot escaped, but his foot was cut off. He managed to carry his foot with him and later ordered his family to preserve the foot carefully, because if it rotted, it would have meant that Sereot would die. It could only be buried on his death. Boro Tura, the head of Watoone, then happened to be in the Dutch governmental office in Waiwerang. When he went to the office, day was setting. He saw the armed gang from Lamalouk, which also spotted him. However, instead of chasing Boro Tura, they were more interested in the unsuspecting large group of workmen. The first target was Masan Siga. His throat was cut, but he was not killed, and he met Boro Tura returning from the office. Boro Tura was told what happened and urged to return to Watoone. Boro Tura and others went to the telephone office and telephoned Hinga, Witihama, and Sagu, to ask what was the reason for the killing of the corvée labourers. But they received no answer. Then they called Kolilanang and were told that people of Muda had recently killed someone from Lamalota and that these grizzly acts were surely the revenge.

As village head, Boro Tura took steps to deal with the wounded and corpses. With the help of the police and Kapitan Bebe ${ }^{2}$ from the village of Adonara, the wounded were taken to Larantuka to be cared for in the hospital. The corpses had to be taken to Watoone. For this purpose, Boro Tura was helped by two soldiers. Guarded by the soldiers he and his companions went to Watoone. But they had to go through Lamalouk and its allied villages. Even with an escort they were frightened.

Before this mass killing, a person from Hinga named Laot Kolot on his way to Lewoduli was killed by people of Lamalota. ${ }^{3}$ His corpse was placed in the road which the group carrying the corpses had to travel, in order to further aggravate them. When they reached

\footnotetext{
${ }^{2}$ Bebe Lego of the clan Sarabiti Waihale who replaced Bapa Ana as Kapitan of Adonara when Bapa Ana became acting Raja in July 1932.

${ }^{3}$ Symons (1934: 9-10) confirms Lamahoda's account of these events, giving the date of each as 21 July. The only discrepancy is that Symons reports only four corvée labourers as being killed in Waiwerang and nine badly wounded. Otherwise Lamahoda's account is more circumstantial.
} 
Lamalouk, their fear reached a peak, because they were awaited by hundreds of armed men, who greeted them with ridicule and hatred. The peak of misery came when they encountered Laot Kolot's corpse, which they also had to pick up while watched by hundreds of men, women and children. Their hearts became lighter once they had passed Lamalouk and neared the border where they were met by hundreds of Paji who were prepared to help.

Baye from Watoone lived in Lamalota where he was married to Lipat from that village. Lipat related that two evenings before these events she learned that people of Lamalota planned to kill the people from Watoone doing corvée labour in Waiwerang. She almost went that evening to Waiwerang to warn her husband, but was afraid because she was by herself and it was getting dark. She hoped that there would still be time in the morning. But when she reached Waiwerang, she learned that Baye was among those who had been killed. People from Lamalouk and its allies were assembled in Waiwerang and investigated to see who had stirred up the affair and who took part, but no one confessed and the investigation was suspended. After the government suspended the case, people of Watoone swore an oath as part of a ritual of revenge. Those of Lamalouk who truly did not take part in the killings would escape any attempt at retaliation, those who did take part would die.

Everyday Boro Tura went to inspect the border. Near the border there were fields belonging to people of Lamalouk. One day around a year after the killings in Waiwerang, Boro Tura suspected that people of Lamalouk would be picking maize near the border. He went to scout and found that his suspicion was correct. He returned and assembled his people. At midday they returned to the spot, where the people of Lamalouk had already prepared to return to their village having placed their maize in baskets. He and his forces quickly surrounded the unfortunate people of Lamalouk, who comprised a single family, two men named Peka Teba and Demon Laban and two women. All four were killed. A hand of one of the men was cut off and stuck on the end of a spear and then taken to Watoone as proof. In order to demonstrate their bravery they returned via Witihama. Relations between Boro Tura and the traditional leaders of Witihama at that time were not good. Even though they were also Paji and from the same complex of villages, the leaders of Witihama reported Boro Tura to the government. Therefore Boro Tura and all of his companions were captured and taken to Larantuka. Only the old, women and children were left in the village (Lamahoda n.d.: 55-56).

Schulte Nordholt writes that 25 heads in all were taken in three months at the time of these killings. The government officer in Larantuka was transferred as punishment because he did nothing to prevent this fight from taking on such proportions. His successor was sacked and received three months imprisonment since he bound suspects to a pole and had palm sugar syrup poured over them, so that they were badly bitten by ants which were quickly attracted by the syrup according to the Indonesia proverb ada gula, ada semut [where there is sugar, there are ants]. In the end over 1,000 years of imprisonment was handed out to those convicted of taking part (Schulte Nordholt 1977: 163-64).

Another person who paid a price for these events was acting Raja Bapa Ana, who replaced Arakian Kamba on his death early in the 1930s. Arndt (1938: 47) refers to the last Raja (of Adonara) who died in prison in Larantuka. Arndt states that he belonged to a clan that came from Seran, but this statement is a confusion. Arakian Kamba and the other hereditary rulers of Adonara claimed descent from Seran. Bapa Ana belonged to the hereditary line of the Kapitan of Adonara, who claimed descent from Enga, offspring of the descent line of the rajas of Larantuka. In Witihama, I was told that when Bapa Ana was regent, someone from Dua killed someone from Lamalota, provoking the revenge killing of Paji in Waiwerang. Bapa Ana could not take the humiliation and stirred up 


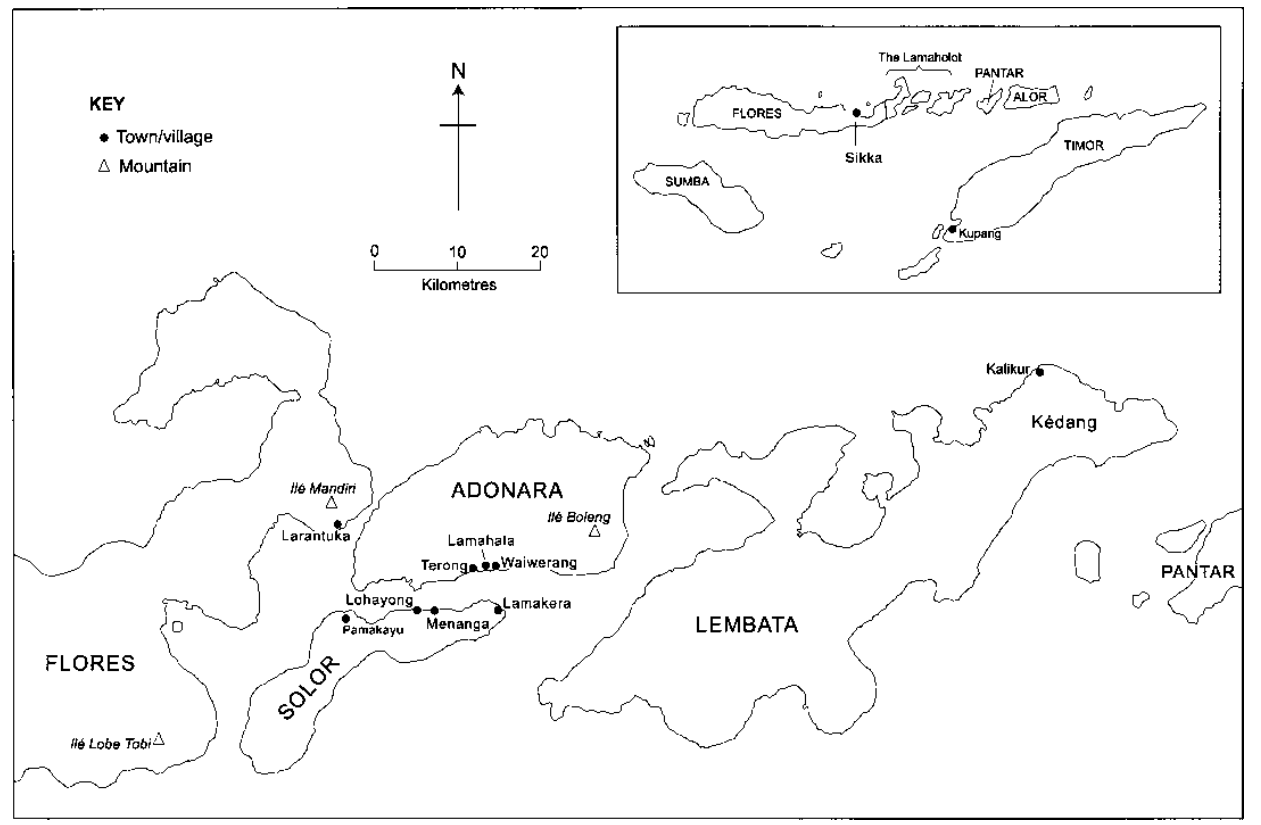

Map 1. East Flores and the Solor Islands

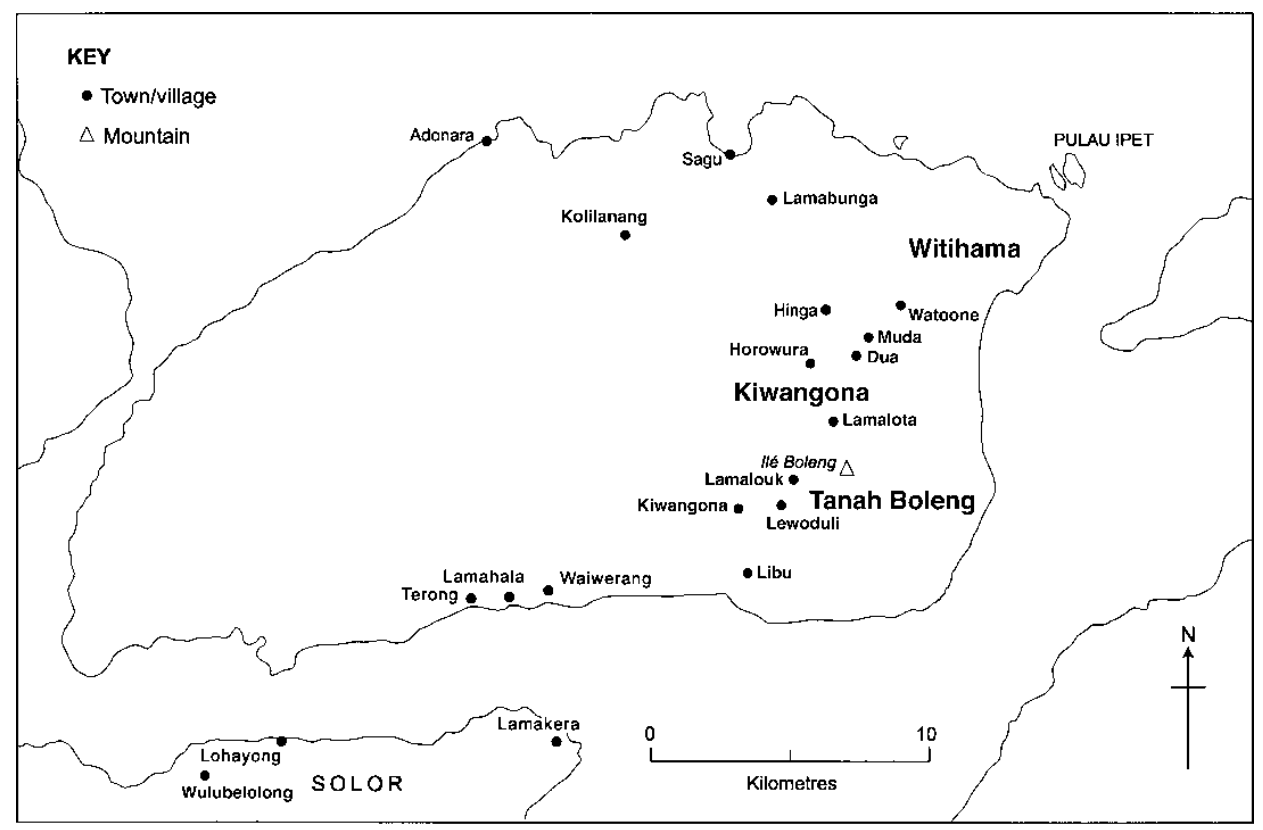

Map 2. Adonora 
the Paji to retaliate. Bapa Nur (brother's son's son of Arakian Kamba), who wanted Bapa Ana out of the way so that he could become raja, notified the authorities secretly, according to one rumour, although Bapa Nur's son, Gelak, did not agree that this account was correct. At any event Bapa Ana and Bebe Lego, the Kapitan of Adonara at the time, were tried and imprisoned.

Bapa Ana's son Arakian Kamba Kéi Helu told me that Bapa Ana paid for Bapa Nur's schooling in Kupang, but this kindness did not prevent Bapa Nur from pulling off a coup d'etat. Bapa Nur blamed the killing of someone from the Demon region by a Paji on Bapa Ana, but, so I was told, Bapa Ana was not guilty. He was arrested and taken to Larantuka. When he arrived at the dock in Larantuka, he was stripped and dressed only in his underclothes. His possessions were seized and sold at auction. He fell ill in the prison, possibly of a heart attack, and was taken to hospital, where he died. His son said that Bapa Ana died in 1937, but the Koloniaal Verslag (1937: 396) says that he died 14 April 1936. The Koloniaal Verslag (1935: 347-48) says that the fighting began on 21 July 1934 and lasted until the government placed three brigades from Larantuka on Adonara, which quickly restored order and peace (see also Symons 1934).

\section{Aftermath}

The peace which was restored was an uneasy peace until the Japanese invasion in 1942. Friends from Lembata who travelled through East Flores in the 1940s have told me that the atmosphere was very hostile when they walked along the main road to Sagu on the north coast through Kiwangona. In 1950 and 1951 eastern Adonara was disrupted during the rebellion of the Persatuan Kaum Tani Indonesia [Union of Indonesian Peasants] under Buang Duran (Barnes 2003). The reaction following the attempted coup in Jakarta in 1965 brought the elimination of elements of the local communist party and the killing of perhaps some 70 alleged communists in the Regency of East Flores. The Suharto dictatorship imposed a harsh discipline which was perhaps more successful than the Dutch, but never completely eliminated low-level conflict. The government and community leaders have tried hard to suppress the Demon and Paji identifications and hostilities. At the moment I should judge that they have been successful, but other, similar conflicts still occur from time to time. I had the privilege of accompanying the brothers Ama Mangan Bahi and Dominikus Dore Bahi to a series of ceremonies they conducted in various places in eastern and central Adonara in 2000 and 2001 to trace the causes of misfortunes to individuals. Not infrequently, the causes they uncovered involved killings. On the other hand I never witnessed a ceremony such as described by Lewokeda in preparation for a murder or one for a reconciliation of the hostile parties after such a death. The impression I had during 14 months residence in Witihama was of happy peacefulness, with just a few regrettable incidents in the villages of eastern Adonara. Certainly neither I nor my friends were ever unsafe, and the atmosphere in Kiwangona was for the most part just as peaceful. The collapse of the Suharto dictatorship had not, by then, led to any increase in overt violence or hostility. In these ways, I was not reliving their past, but I was given plenty of first-hand reports of how grim that past sometimes was by my host and others who had lived through it.

\section{Note}

This article is the outgrowth of many research trips beginning in 1969, but most of the information in it derives from research conducted in Witihama, Adonara, between 
August 2000 and September 2001. That research was supported by grants from the British Academy, the Committee for South East Asian Studies of the British Academy, and the Oppenheimer Fund. The research was carried out under the auspices of the Indonesian Institute of Sciences. I am grateful to all institutions and persons who have, in their manifold ways, supported my research.

\section{R.H. Barnes}

University of Oxford

Institute of Social and Cultural Anthropology

51 Banbury Road

Oxford OX3 7RR

UK

Email: robert.barnes@anthropology.ox.ac.uk

\section{References}

Andaya, Leonard Y. 1993. The world of Maluku: Eastern Indonesia in the early modern period. Honolulu: University of Hawa'i Press.

Arndt, Paul 1938. Demon und Padzi, die feindichen Brüder des Solor-Archipels. Anthropos 38: 1-58.

Arndt, Paul 1951. Religion auf Ostflores, Adonare und Solor. Studia Instituti Anthropos, vol. 1. Wien-Mördling: Verlag und Druck der Missionsdsruckerei St. Gabriel.

Barnes, R.H. 1987. Avarice and iniquity at the Solor fort. Bijdragen tot de Taal-, Land-en Volkenkunde 143 (2/3): 208-36.

Barnes, R.H. 1993. Construction sacrifice, kidnapping and head-hunting rumors on Flores and elsewhere in Indonesia. Oceania 64 (2): 146-58.

Barnes, R.H. 2003. Fransiskus/Usman Buang Duran: Catholic, Muslim, Communist. Bijdragen tot de Taal-, Land-en Volkenkunde 159 (1): 1-29.

Barnes, R.H. 2005. Hongi Hinga and its implications: a war of colonial consolidation in the Timor residency in 1904. Bijdragen tot de Taal-, Land-en Volkenkunde 161 (1): $1-39$.

Beckering, J.D.H. 1911. Beschrijving der Eilanden Adonara en Lomblem, Behoorende tot de Solor-Groep. Tijdschrift van het Koninklijk Nederlandsch Aardrijkskundig Genootschap, $2 e$ Serie 28: 167-202.

Cacegas, Luiz and Luis de Sousa 1678. Primeira Parte da Historia de S. Domingos, particular do Reino e Conquistas de Portugal, vol. 3. Lisbon: de Vinha.

Dietrich, Stefan 1989. Kolonialismus und Mission auf Flores (ca. 1900-1942). Hohenschäftlarn: Klaus Renner Verlag.

Duyvendak, J.P. 1926. Het Kakean-genootschap van Seran. Almelo: Drukkerij N.V. W. Hilarius.

Fox, James J. 1986. The ordering of generations: change and continuity in old Javanese kinship. In David G. Marr and A.C. Milner (eds), Southeast Asia in the 9th to 14th centuries. Singapore: Institute of Southeast Asian Studies/Research School of Pacific Studies, Australian National University.

Koloniaal Verslag 1914. Koloniaal Verslag van 1914.

Koloniaal Verslag 1935. Koloniaal Verslag van 1935.

Koloniaal Verslag 1937. Koloniaal Verslag van 1937.

Lamahoda, Stevanus Kopong Keda n.d. Peperangan2 dan Dendam. Unpublished. 
[Lewokeda], Karolus Kopong Medan 2002. Murder ritual on Adonara, Indonesia: a cultural analysis. Translated from Indonesian by R.H. Barnes. Anthropos 97: 487-94.

Lulofs, C. 1911. Toepassing en Resultatent van de Nieuwere Beginselen van Politiek Belied in de Residentie Timor en Onderhoorigheden. Tijdschrift voor het Binnenlandsch Bestuur 40: 281-308.

Rassers, W.H. 1959. Panji, the culture hero: a structural study of religion in Java. The Hague: Nijhoff.

Reid, Anthony 1969. The contest for North Sumatra: Atjeh, the Netherlands and Britain 1858-1898. Kuala Lumpur: Oxford University Press/University of Malaya Press.

Roever, Arend de 2002. De Jacht op Sandelhout: De VOC en de Tweedeling van Timor in de Zeventiende Eeuw. Zutphen: Walburg Pers.

Rouffaer, G.P. 1923-24. Naschrift over het Oud-Portugueesche Fort op Poeloe Ende: en de Dominikaner Solor-Flores-Missie, 1561-1638. Nederlandsch-Indië Oud en Nieuw 8: $121-28,141-48$.

Santa Catharina, Lucas de 1733. Quarte Parte da Historia de S. Domingos. Lisbon: Academia Real.

Seegeler, C.J. 1931. Nota van Toelichting betreffende het zelfbesturende landschap Larantoeka. Algemeen Rijksarchief (Nationaal Archief). The Hague. Unpublished.

Schulte Nordholt, H.G. 1977. Besturen in een vacuüm. In S.L. van der Wal (ed.), Besturen Overzee: Herinneringen van oud-ambtenaren bij het binnenlands bestuur in Nederlandsch-Indië. Franeker: Wever.

Symons, J.J.M. Verslag omtrent den toestand op het eiland Adonara naar aanleiding van de gebeurtenissen in Juli en September 1934. Algemeen Riksarchief (Nationaal Archief). The Hague. Unpublished.

Tauern, Odo Deodatus 1918. Patasiwa und Patalima vom Molukkeneiland Seran und seinen Bewohnern. Leipzig: R. Voigtländer Verlag.

Vatter, Ernst 1932. Ata Kiwan: unbekannte Bergvölker im tropischem Holland. Leipzig: Bibliographisches Institut.

Wertenbroek, M.J.H.M. n.d. Notes. Unpublished. 